\title{
The Undercommons and Subjugated Knowledge: The Powers of Non-State Practices that Decolonize Knowledge
}

\author{
Jessica Malandrino* \\ Department of Socio Legal Studies, Canada
}

*Corresponding author: Jessica Malandrino, Department of Socio Legal Studies, Canada.

\author{
Received Date: January 16, 2019 \\ Published Date: February 12, 2019
}

\section{Introduction}

In Michel Foucault's work, Power/Knowledge: Selected Interviews and Other Writings 1972-1977, I am interested in thinking about the relationship with his theory about power and knowledge. For Foucault, power and knowledge is within the "articulation of each other [1]." In this, there is a type of knowledge and hypervisibility that has a historical tone, and this feature is scientific [2]. For this essay I will summarize some of Foucault's theories about power and knowledge, because it provides a pedagogy to think about the performative structure of knowledge. In that, there is a performance of power that upholds certain knowledge as important. Foucault's argument that I am interested in are how the state produces discourse that is scientific and upheld socio-historically. More specifically, I am interested in his ideas about "subjugated knowledge," because this can be either unconscious and ideological knowledge that is informed by history, or outside knowledge, non-state knowledges of everyday life and experience [3]. What I am really interested in for this critical response is to extend Foucault's ideas about knowledge that is not seen as important to the state. In this essay, I put forth the following questions: How does the state evaluate knowledge as important? How can we think, and use knowledge outside of the state's power? I will attempt to answer these questions in this essay.

I argue that we should complicate legal and medical structures of knowledge and use decolonial practices to theorize statecentered knowledge as repressive and constructive. The institutions of the state that I will draw on specifically, in relation to Foucault's theory of power and knowledge, will be informed by my argument that states, social structures of legal and medical epistemologies are weighed as important to control and understand the Otherone who is criminal, deviant, non-white, or, a woman-that has dominated discourse of pathologizing and correction. This paper will trace some of the many ideas that Foucault had about power and knowledge through his other book I mentioned ago, as well as Discipline and Punish: The Birth of the Prison. I find that throughout these two texts, Foucault critiques the historical method as a methodology, and as a result, he ruptures legal and medical discourse through these lectures, essays, and books. The rupture I am referring to is how Foucault highlights the state-power relationship with performing knowledge, and specifically, thinking through how the state anchors certain discourse that reproduces the power of the state while subjugating the Other's history. Here I am pointing to history of colonization for example, one that is suppressed through dominant discourses of knowledge [4].

In stark contrast from Foucault, I will draw on Fred Moton and Stefano Harney's s book The Undercommons: Fugitive Planning and Black Study, because their center of reform is decolonial. The site of knowledge that they rupture is through what they call, "the undercommons [5]." That is, an agent to regrind a new society that "disturbs and at the same time forms" against the "power of the university" and dominant discourse of the state [6]. I draw on these theorists alongside Foucault, to think about and understand the Other's place of knowledge that can be held to the experiences of everyday life, that I maintain through Moton and Harney's theories about the undercommons.

As a point of entry for this critical review, I will draw on Foucault's book Power/Knowledge. First, I want to have a conversation about his questions "How is it that we have progressed?" and "What happens now?" [7] Foucault begins to answer these questions through his intervention of discourse, where he "makes visible the unseen" and to a certain degree, he does this is by calling out the repetitions within the "relationship between power and knowledge [8]." I am going to unpack this relationship briefly. Foucault argues that power and knowledge is an "articulation of each on the other," that functions to reproduce the power of state-created discourse, 
which in turn buries hidden artifacts, that I argue blurs histories of the Other [9]. I think that Foucault argues that through his digging of discourse, he sees that those with power uphold power that is contingent on repetitive knowledge, therefore, power cannot exist without knowledge and vice versa. To illustrate, within legal and medical systems, Foucault argues that there is a linear construction of historical events, one that he wishes to deconstruct through human events and history. The tools in which Foucault carries this out is through periodization-a linear construction of historical events, particularly in the layering of knowledges or claims that are chronological in history [10]. For example, he states, "It has been tradition for humanism to assume that once someone gains power he ceases to know," although those non-state actors who distance themselves from power, Foucault argues, "only they can discover the truth [11]."

In these ways, Foucault argues that only non-state actors can reverse the gaze back on legal and medical articulation of knowledge. These institutions structure gaps of artifacts that blur periodization's history of social bodies and social structures to maintain power and knowledge relations. For instance, he says, "Now I have been trying to make visible the constant articulation I think there is of power on knowledge and of knowledge on power" since "new objects of knowledge" can "accumulate new bodies of information [12]." Foucault theorizes this relationship between power and knowledge as productive for the state to predict non-state actors' social bodies and social structures [13]. Here, pathologies of mentally or criminally deviant people can be seen as constructive by state-power relations. The power and knowledge discourse Foucault is invested in this book are mostly that of medical knowledge that are transferred into historical facts, since he states, "I wanted to find out how the medical gaze was institutionalized, how it was effectively inscribed in social space, how the new form of the hospital was at once the effect and the support of a new type of gaze [14].” As one of the centers of interest Foucault argues that the time of this gaze was in the second half of the eighteenth century, and this is where he traces how "the whole problem of the visibility of bodies, individuals and things, under a system of centralized observation, was one of their most constant directing principles [15]."

In line with this idea of medical diagnosis and knowledge, Foucault draws on this in Discipline and Punish. He states, there was a "political investment of the body is bound up, in accordance with complex reciprocal relations [16]." One, "it is largely as a force of production that the body is invested with relations of power and domination [17]." Two, these relations were carried through the gaze that is "integrated into any function (education, medical treatment, production, and punishment" that all mix "relations of power and knowledge" to be "supervised" through the gaze [18]. To categorize and flesh out the Other, Foucault argues that those with power in legal and medical institutions-controlled folks through "binary division and branding (mad/sane; dangerous/harmless; normal/abnormal) [19]." These people, for Foucault, needed to be corrected through the state that could discipline people through medicine and carceral punishment.

For the law makers treatment of the criminal, Foucault argues that legal institutions in the mid-17th century shifted from the "torture as a public spectacle" from the scaffold to the prison [20]. This knowledge for Foucault, meant that "Punishment, then, will tend to become the most hidden part of the penal process," which he wanted to unpack and reveal throughout this book [21]. By examining histories of legal apparatuses, Foucault argued that the criminal was subject to objectives such as, "make of the punishment and repression of illegalities a regular function, coextensive with society; not to punish less, but to punish better [22]." In turn, insert this power of knowing what will happen if you commit crime that will "punish more deeply into the social body [23]." In these ways, Foucault's book argues that "A great prison structure was planned, whose different levels would correspond exactly to the levels would correspond exactly to the levels of the centralized administration. The scaffold, where the body of the tortured criminal had been exposed to the ritually manifested force of the sovereign, the punitive theatre in which the representation of punishment was permanently available to the social body, was replaced by a great enclosed, complex and hierarchized structure that was integrated into the very body of the state apparatus [24]."

Here, I think that Foucault's ideas about knowledge and legal officials power links together the construction of criminal behavior, and the consequences this threat of the criminal has on societies that allowed legal figures to punish best, even if this meant social or literal death. I think that Foucault's efforts in both Power/ Knowledge and Discipline and Punish, intended to reveal the ways in which the state observes and controls society to impute their power relations. Overall, Foucault's ideas about "subjugated knowledge" that the state brings under control is one that are historical and dominating to inflict and manage social bodies through legal and medical apparatuses [25]. These knowledges, I think Foucault argues is performative and constructive to center particular histories and identities and acute state-sanctions as normal-punitive and corrective to name a few.

\section{Procedure}

However, I want to step away from Foucault to draw on Moton and Harney to think about understanding of the Other-one who is criminal, deviant, non-white, or, a woman-in a framework that is not centered on legal and medical knowledges, or power relations of everyday life. Or, if you want to think about it in Foucauldian terms, I will turn to the second kind of subjugated knowledge that is, outside knowledge. I use these theorists to think through the ideas put forth within the emblem of the undercommons-because I want to think about knowledge differently than Foucault for a second. Drawing on Jack Halberstam's introductory chapter of this book, he says that the undercommons is not where you "come to pay" something like "debts, to repair what has been broken, to fix what has come undone [26]." Rather, the undercommons is "a space and time which is always here" and in these ways, the undercommons are our everyday that is situated in moments that are outside of the state, a center to decolonize violence inflicted by the state [27]. In these ways the moments of everyday life that Moton and Harney argue for, should empower you to "refuse order as the distinction between noise and music, chatter and knowledge, pain and truth" and, in turn, we should "make and to refuse the offers we receive to shape that noise into music [27]." 
Rather than thinking about Foucault's ideas that we are trapped in power systems of legal and medical officials, Moton and Harney are some of the many theorists that think about everyday life. To illustrate, further I draw on an example of what I write about that can be theorized as the space of my undercommon. I state:

In the day of the dead, I wash my face for preparing for bed. This night was different the mirror held another reflection one that follows me in the dark. He looks in anger standing there cold in fog the glass is clear, and he is disappointed again.

For this moment, I use poetry to speak to power and knowledge of the state through something that is outside of state practices. My poetry captures my everyday moments that be of happiness, sadness, pain, or joy. In thinking with Moton and Harney, my writing is not for anyone of legal and medical figures. Instead, I believe in their conception of "another world" one that is "subversive" to the "intellectual" because I am, (unlike Foucault) "neither trying to extend the university nor change the university, the subversive intellectual is not toiling in misery from this place" that generates certain kind of knowledge [27]. Preferably, and similar to Moton and Harney, the moments that I write, I "recognize that when you seek to make things better, you are not just doing it for the Other, you must also be doing it for yourself [27]." Again, I am speaking to the Other-one who is criminal, deviant, non-white, or, a woman. Inspired by Moton and Harney, I resonate with the idea that "she does not want a room of his or her own, she wants to be in the world with others and making the work anew," which is my favorite quote of the book and I think the most important moment throughout this essay [27].

\section{Conclusion}

Above everything else, this paper has outlined some of the many ideas that Foucault had about power and knowledge through both Power/Knowledge and Discipline and Punish: The Birth of the Prison. Particularly, this paper focused on Foucault's use of historical method as a methodology, and to demonstrate the ways in which he carried this out through both of these books mentioned. I focused on his analysis of legal and medical institutions that inflict power and knowledge on social regimes and held subjugated knowledge as an object of analysis for this paper in an extended terrain in thinking about outside knowledge as a decolonial practice. I also focused on the experience of the Other that I described a few times in this essay as being constructed as an abject person due to scientific discourse that choose not to repeat interventions of their everyday life. Interventions like Moton and Harney's offer an abolitionist way of reading Foucault's work that I found to coincide with my own work, hence using it for this essay. Abolishing power relations and thinking about making new practices of affect is one that my work finds important as a restorative approach to the state's harmful legal and medical figures-who supposedly know best.

\section{Acknowledgement}

None.

\section{Conflict of Interest}

No conflict of interest.

\section{References}

1. See Michel Foucault in Power/Knowledge: Selected Interviews and Other Writings 1972-1977: 51.

2. Although this review will be anchored in Foucault's work about reproducing dominant histories of knowledge that hold power, I will also try to stray from this discourse in offering a different trajectory. I will borrow feminist thinkers in critically reviewing and analyzing centers of violence that perhaps, borrow and extend Foucault's ideas in thinking about abolition of power and knowledge, ibid 51.

3. Ibid 81

4. See Canadian history of residential schools for indigenous people and the ways in which this knowledge is repressed by the state through the performance for example, of the Canadian national anthem. All Canadians in this country don't 'stand tall and free,' rather it is argued that indigenous people have suffered a history of colonization and their land is stolen and they are oppressed within the state of Canada. However, this knowledge is not one that is as voiced as Canada's history of World War I-an event that is celebrated and reflected on by Canadians. These examples are the two Foucault argues for through his concept subjugated knowledge. Although, my example is decolonial, one in which Foucault didn't center on this book.

5. More broadly, the critique these theorists use against Foucault's ideas about power and knowledge, can be seen a little more in depth here. For them, the state reproduces and creates knowledge that is understood as most important. I argue that this is due to repetition and history of motifs. Borrowing Moton and Harney's ideas, I extend them in argument that the undercommons do not rely on white men with positions of power-in this, instead I would argue that the undercommons is a space to think, reform and heal from dominant ways of knowing, and focus on everyday experience. See Fred Moton and Stefano Harney's book, The Undercommons: Fugitive Planning and Black Study: 40.

6. Ibid: 40 .

7. Foucault, Power/Knowledge: 50 .

8. Ibid: 50 .

9. Ibid: 51

10. Ibid: 51 .

11. Ibid: 51.

12. Foucault, Power/Knowledge: 146.

13. Ibid: 146 .

14. Foucault, Discipline and Punish: 25.

15. Ibid: 26

16. Ibid: 206.

17. Ibid: 199

18. Ibid: 7.

19. Ibid: 9.

20. Ibid: 82

21. Ibid: 82 .

22. Ibid: 115 .

23. Foucault, Power/Knowledge: 81.

24. Moton and Harney: 9

25. These are Jack Halberstam's words in the introduction where he for a moment discusses Moton and Harney's ideas and describes what the undercommons do, ibid: 9.

26. Moton and Harney: 9

27. Ibid: 10 . 